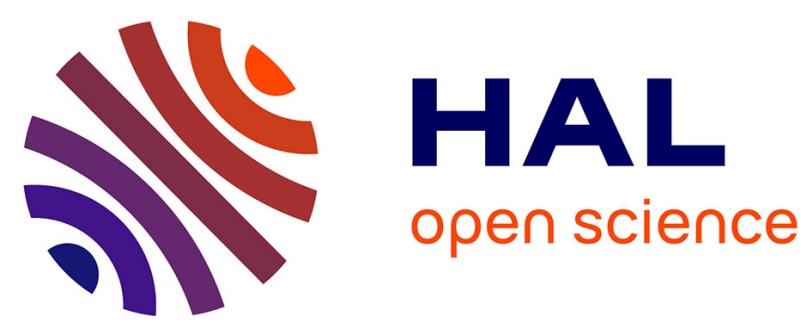

\title{
Follow the leader: how corporate social responsibility influences strategy and practice in the business community
}

\author{
Farid Baddache, Isabelle Nicolaï
}

\section{To cite this version:}

Farid Baddache, Isabelle Nicolaï. Follow the leader: how corporate social responsibility influences strategy and practice in the business community. Journal of Business Strategy, 2013, 34 (6), pp.26-35. hal-01710072

\author{
HAL Id: hal-01710072 \\ https://hal.science/hal-01710072
}

Submitted on 15 Feb 2018

HAL is a multi-disciplinary open access archive for the deposit and dissemination of scientific research documents, whether they are published or not. The documents may come from teaching and research institutions in France or abroad, or from public or private research centers.
L'archive ouverte pluridisciplinaire $\mathbf{H A L}$, est destinée au dépôt et à la diffusion de documents scientifiques de niveau recherche, publiés ou non, émanant des établissements d'enseignement et de recherche français ou étrangers, des laboratoires publics ou privés. 


\title{
Follow the leader: how corporate social responsibility influences strategy and practices in the business community
}

Farid Baddache the European Branch Director of BSR - Business for Social Responsibility, and visiting University Professor at the REEDS - University of Versailles Saint-Quentin-en-Yvelines farid.baddache@uvsq.fr.

Isabelle Nicolaï, Professor in Economics, REEDS, University of Versailles Saint-Quentin-enYvelines, 5 Boulevard d'Alembert, 78047 Guyancourt Cedex, France. + +33 $68388 \quad 1255$ isabelle.nicolai@uvsq.fr corresponding author

\begin{abstract}
Purpose: Companies face increasing pressure from stakeholders to play a leading role in addressing a wide array of environmental, social, and governance issues. What are the relevant and responsible contributions that corporations are expected to provide in support of defining solutions to sustainability issues? This paper shows how corporate social responsibility (CSR) has become a negotiation process to help corporations manage uncertainties through collaborative work and alignment with stakeholders. From that angle, CSR is a process that generates standard and acceptable business practices.

Design/methodology/approach: This paper uses both an adductive as well as an interpretative approach of CSR and looks at CSR as a collaborative process that builds rules and norms.

Findings: CSR is defined as a contractual process between stakeholders in order to drive decision making processes and agree on commitments between business and society. Interestingly, all studied examples depict the development of standard and acceptable business practices with very little involvement of stakeholders, which is not the understood way of driving changes to business strategy as defined by the CSR negotiation processes.

Practical implications: A framework is presented linking CSR business practices research findings to empirical market isomorphism. The paper is of practical relevance for management practitioners. The limitations of recent research are also discussed.

Originality/value: Our examples show that CSR is no more than the achievements of fragmented initiatives led by companies showing limited transparency toward external stakeholders. There is no overall coordination. The paper is original in its recommendation that public authorities play a strategic role showing clear direction, and establish themselves as a strategic platform enabling more engagement between stakeholders.
\end{abstract}

Keywords: stakeholder theory, CSR business practices, negotiation, institutional economic theory, network organization, isomorphism

Paper type: Research paper 


\section{Follow the leader: how corporate social responsibility influences strategy and practices in the business community}

Companies face increasing pressure from stakeholders such as governments, consumers, and employees to play a leading role in addressing a wide array of environmental, social, and governance issues - ranging from climate change to water preservation or human rights. But who is responsible for each of these issues, and who is expected to take action?

CSR can be defined as a contractual process to define relationships between stakeholders, to drive the decision making processes, to set expectations and to agree on commitments between the business world and society. This is an ongoing process-expectations and commitment evolve over time. This theory postdates classical stakeholder theories as new multidimensional stakeholder dynamics continue to emerge.

The methodology in this paper focuses on describing and understanding the dynamic processes supporting the way in which corporations define solutions to address stakeholder expectations. This paper integrates a neo-institutional framework which looks at CSR as a collaborative process to build rules. We use an abductive approach to focus on five factors generating market standard and acceptable business practices : stakeholder mapping, motivations, level of ambition, level of governance and transformational change.

This paper's contribution is to illustrate how the CSR decision making process can generate acceptable business practices for corporations. In the first part, we analyse how these "isomorphisms" define a continuum of business answers to sustainability. The second part describes empirical standard and acceptable business practices and depicts their development, which is led by corporations.

\section{CSR as a decision making process leveraging isomorphism in management processes}

\section{a) CSR as a conventional rule to cooperate}

CSR may be considered a network of actors managing conflicts and coordinating productive activities. As such, CSR is an institution looking at ways to reduce the occurrence of potential conflicts within a given stakeholder community.

The Dutch Social Economic Council (SER, 2000/11) gives the following definition of CSR: "CSR is the art of "being responsible in a responsive way" and we envision it thus as a tool to focus on ways of using corporate capacity to build interactions with social groups of stakeholders. That being said, CSR is not just about contractually agreeing on acceptable solutions. From the perspective of stakeholder and contract theory (Hill and Jones, 1992; Kahler, 2009), the ability to reach an agreement is indeed an outcome of a given process, and not the process itself. As a consequence, understanding the overall collective process shaping the contractual definition is more important than looking at the outcomes of those processes.

In this regard, CSR is a process in which networked actors negotiate rules and standards that they collectively commit to respect (report to Habermas discussion ethical principle, 1991). It is possible to understand the processes and motivations driving the way corporations define solutions through CSR efforts to address pressures from their stakeholders. CSR is thus a conventional rule (Sugden, 1989) making it possible for stakeholders to identify areas of mutual interest, to produce rules or norms together, and to increase compliance.

\section{b) How the CSR institution generates standard and acceptable business practices}

A corporation's level of CSR commitment should be seen a dynamic process to agree on rules with different stakeholder communities. We intend to show that as soon as a prominent corporation makes institutional arrangements with its stakeholder communities (value chain, peers, knowledgeable content owners and influential pressure makers for instance), the rest of the business community and stakeholder communities also align on similar expectations and arrangements. This is what we call standard and acceptable business practices or market isomorphisms. 
Informally, an isomorphism is a kind of matching between objects, showing a behavioral convergence between two organizations.

CSR through negotiation processes generates different types of managerial responses. Concept of isomorphism, showing how independent business initiatives can shape standard and widely business practices is interesting to explain the dynamics of managerial responses to address stakeholder expectations. Di Maggio and Powell (1991) define the three following types of isomorphisms:

- Isomorphism under pressure. The instance where all companies adopt a given CSR strategy as a response to a new regulation. An illustrative example are the European Union's directives that increasingly impose limited levels of $\mathrm{CO} 2$ emissions to all automotive companies Regardless of lobbying efforts, this examples shows a clear trend forcing car makers to reduce $\mathrm{CO} 2$ emissions under a $120 \mathrm{~g} / \mathrm{km}$ standard in the near future.

- Isomorphism under normalization. The instance where all companies adopt the same ways of managing their processes using the same normalization standards. As an example, ISO management has extensively demonstrated howprinciples without sanctions can homogenize practices within various organizations . With quality at the center of their corporate cultures, many industrial sectors have decided to enhance their quality processes to increasingly include CSR principles.

- Mimic isomorphism. The instance where all companies copy a peer or an institution's definition as soon as this initiative gains legitimacy. Max Havelaar, a private based initiative that set a standard for fair trade, has brought great legitimacy to multiple stakeholder communities over time. Today, all retailers have engaged in the fair trade business, and most have adopted the Max Havelaar standard. Those who have decided to define their own standard cannot avoid making some official comparison with Max Havelaar in order to obtain legitimacy. Legitimacy comes both from public opinion (opinion formers, consumers) as well as from the definition of a law or a standard (Deephouse, 1996)

In addition to these business governance practices we propose a fourth based on social innovation. Various works on Base of the Pyramid issues (BoP) (Prahalad and Hammond 2002; Karnani 2007) have generated massive interest for social innovation to define new services for low-income consumers in developing markets. This is not a mere instance of mimic isomorphisms, since the social innovation field questions more than just legitimacy and instead generates truly new business models. Social innovation is a driverfor each company to define its own system of innovation to access new markets with social needs.

In fact, these different isomorphisms define together a continuum of business answers toward sustainability (Oliver 1991; Barabelm et alii, 2010)

\begin{tabular}{|l|l|}
\hline Isomorphism typology & Gradual commitment \\
\hline Under pressure & $\begin{array}{l}\text { Refrain from changing but need to } \\
\text { adapt to new market rules }\end{array}$ \\
\hline Under normalization & Agree on market practices \\
\hline Mimic & Assimilate principles \\
\hline Social innovation & Engage for proactive changes \\
\hline
\end{tabular}

Starting from these typologies, which describe various outcomes obtained through the CSR negotiation process, we therefore propose an empirical typology of different strategies adopted by companies to build and negotiate collective commitments that generate standard and acceptable business practices. 
The applied research methodology is abductive, which means that it is based on an approach selecting hypothesis which are likely to explain "surprising" observations. We would like to uncover possible factors leading to CSR as a process generating standard and acceptable business practices within a neo-institutional framework.

We will focus on the following factors generating behavioral convergences between organizations:

A. Stakeholder mapping: Is there a clear stakeholder landscape? Are these stakeholders part of the network contributing to contractual processes? Is there a clear understanding and qualification of stakeholder expectations? (Garriga and Mele, 2004; Fassin, 2009)

B. Motivations and interests: Given available and known information at a particular moment, what is the level of motivation for stakeholders to actively take part in already underway processes? There are many factors which may impact motivation to take part in a process such as price signals, risk management, compliance (Porter and Kramer, 2010) competitive advantages (e.g.: eco efficiency), or aversion to change. . Motivations may significantly vary depending on the contextual environment as well: across geography, over time, or even depending on social class.

C. Level of ambition looking at desired outcome: Variables such as pressure levels, expectations and emulation among stakeholders also impact ambition and desired stakeholder attitudes, such as defensive, follower, or proactive (Boiral, 2006; Hall and Vredenburg, 2005).

D. Level of governance: The way stakeholders structure interactions within the network of actors also defines the level of transparency on decision makingand agreements on certain commitments. Governance may vary depending on influence and the level of process' consistency (Van den Hove, 2006):

○ "denying" (there is no desire to make decisions)

- "testing the water" (some stakeholders make decisions on their own and do not really care about what other may expect)

- "hierarchy" (some stakeholders agree to be on the same decision-making level and do not care what other expect)

- "consultation processes" (some stakeholders define a solution, which is open to adjustment based on an active consultation process involving other stakeholders)

- "collaborative processes" (as many stakeholders as possible are involved in a structured process and can all impact decisions)

E. Tools driving transformational change and embedding sustainability considerations into strategy or operations: A process ensuring compliance and accepting feedback to adjust solutions which can consist of:

- "denying": (no decision, hence no follow up process of execution)

- "voluntary statement" (some stakeholders make announcements)

- "monitoring process" (some stakeholders commit to monitor an issue and maintain open discussions)

- "quality assurance" (some stakeholders commit to a contractual framework of improvement, which they embed into their activities of responsibility)

- "quality assurance with third party verification" (beyond a quality assurance level, stakeholders responsible for embedding solutions make it possible for other stakeholders to have access to information and check on actual implementation impacts)

Our analysis will show that the four somorphism typologies are based on these five factors. We will assess the dimensions of these five factors using a Likert scale with scores from 1 to 5, 1 indicating a marginal change on the analyzed dimension (zero represents no change). The framework in this paper is built on direct examples based on the following aspects of CSR (Baddache, 2004):

- relationships are built throughout the investigation process

- the contextual environment heavily impacts causes and their effects

\section{Empirical standard and acceptable business practices}

The following examples test the above hypothesis using real life examples. 


\section{a. Under pressure market isomorphism: Redistributive carbon tax}

Denmark has set the target of using $85 \%$ renewable energy by 2030 . This notably requires a massive development of off-shore wind farms, the use ofoff-peak power generation, battery charging infrastructure and the wide-scale usage of electrical vehicles. As a response to this challenge, the "Better Place" initiative was launched as a multi-stakeholder effort to develop and coordinat efforts to transition infrastructures to a low carbon-emission system; electric cars, gas stations enabling electric battery charging, logistics enabling the transportion of batteries from gas stations to wind farms, smart grid systems for better management of peak and off-peak power generation, consumer education to raise awareness and to increase their acquisition of electric cars. Most interestingly, this whole initiative responds to the development of a new regulation taxing carbon. Companies are therefore working under regulatory pressure to adapt to new market rules. This is an isomorphism under pressure.

We assess this initiative along the following lines:

- Stakeholder mapping is limited and thetopic is fairly technical. This is primarily a business-togovernment initiative with limited contribution from other stakeholders except for some universities.

- Denmark does not want to give a competitive advantage to participating companies. For instance, Renault has been involved from the beginning, and is now forced to accept the presence of competitive car makers, such as the giant Chinese company BYD, as part of the negotiation. In that sense, the process must be rated at a low competitive advantage level.

- Level of ambition scores very high: this initiative wants to transform infrastructures to develop low carbon mobility on a large scale

- Governance is based on consultative processes in the Danish environment which is more consensual than average.

- Transformational process is about the collective agreement on principles (e.g.: standard batteries which different automakers can plug into their own cars). I.e., utomakers agree on standards with input from other stakeholders. There is, however, some commercially sensitive information in the way automakers design their own technical solutions.

\begin{tabular}{|c|c|c|c|l|l|}
\hline & $\begin{array}{l}\text { Stakeholder } \\
\text { mapping }\end{array}$ & $\begin{array}{l}\text { Motivations } \\
\text { \& interests }\end{array}$ & $\begin{array}{l}\text { Level of } \\
\text { ambition }\end{array}$ & $\begin{array}{l}\text { Level of } \\
\text { governance }\end{array}$ & $\begin{array}{l}\text { Transformational } \\
\text { change }\end{array}$ \\
\hline Under pressure & 2 & 3 & 5 & 4 & 3 \\
\hline
\end{tabular}




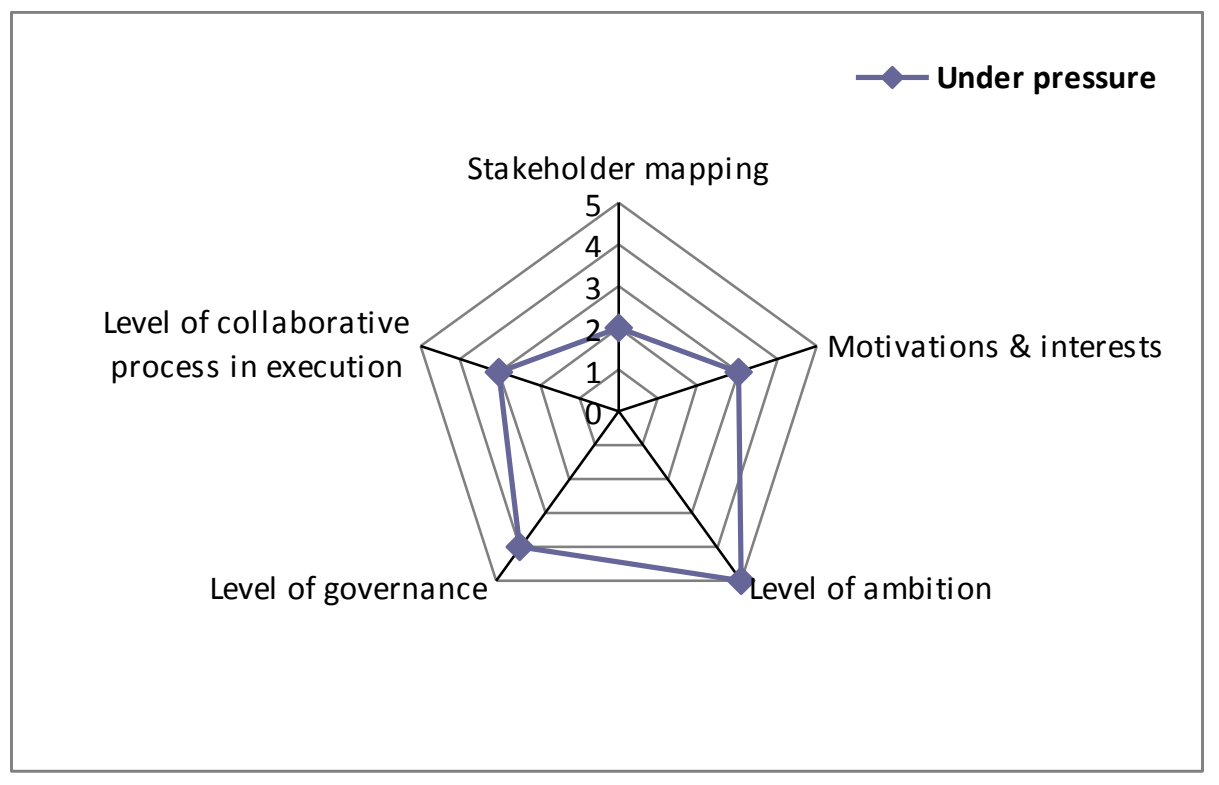

This empirical example shows how a new regulation on redistributive carbon tax indeed forces all companies to adopt a given CSR strategy as a response. We have here "walk or die" dynamics, where the automotive industry witnesses a massive market isomorphism driven by CSR and needs to keep up or lose a major market opportunity that might indeed become the more profitable mobility business by 2020. This isomorphism is characterized by a focus on governance and implementation with pressure coming from regulation or public authorities.

\section{b. Under normalization market isomorphism: Reinsurance power}

Reinsurance and insurance companies need to find new financial models to finance climate change impacts (see the Stern Report for an economic evaluation). The Belron/AXA partnership is an interesting initiative using the emerging environmental concerns of customers to drive operational efficiency in daily operations, and to proactively capitalize to face potential costs of impending natural disasters.

Belron is the world leader in car windscreen repairing. AXA is a major global insurance company. Belron has been a strategic supplier for AXA. These two companies teamed up to jointly advertise on a campaign to "fix your car windscreen instead of changing it". Each company perceived a growing consumer expectation for ecologically friendly behaviors, and together theircampaign encourages clients to make a quick fix in the windscreen rather than asking for a full window replacement, which ultimately generates more waste but is also more expensive. Replacing a windscreen can indeed cost four times more than a mere solid glue repair of the window.

We assess this initiative along the following lines:

- Stakeholder mapping is very limited. This is a business initiative. Other stakeholders are not directly consulted.

- The initiative's ambitions are to streamline cost.

- Companies are adapting to pressures coming from reinsurance companies. Swiss Re for instance has expressed strong concerns for insurance companies to reduce operational costs and better capitalize to face climate change incidents.

- Governance is limited. This is a partnership with two companies driving an initiative of their own, without direct inputs from other stakeholders

- The transformational process is a voluntary statement. Other stakeholders have no access to information, and cannot verify whether this type of initiative effectively enables better anticipation of costs induced by climate change incidents 


\begin{tabular}{|c|c|c|c|c|c|}
\hline & $\begin{array}{l}\text { Stakeholder } \\
\text { mapping }\end{array}$ & $\begin{array}{l}\text { Motivations } \\
\text { \& interests }\end{array}$ & $\begin{array}{l}\text { Level of } \\
\text { ambition }\end{array}$ & $\begin{array}{l}\text { Level of } \\
\text { governance }\end{array}$ & $\begin{array}{l}\text { Transformational } \\
\text { change }\end{array}$ \\
\hline $\begin{array}{c}\text { Under } \\
\text { normalization }\end{array}$ & 2 & 3 & 3 & 3 & 2 \\
\hline
\end{tabular}

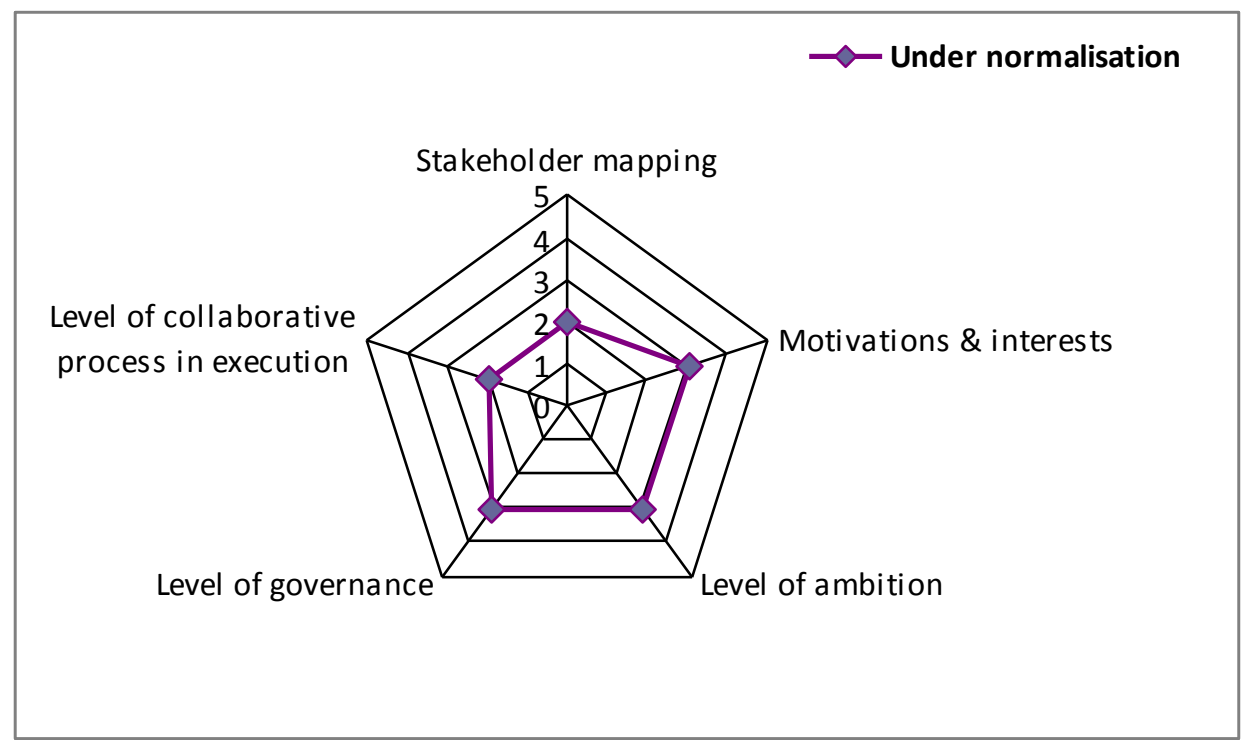

This empirical example shows how reinsurance norms driven by sustainability expectations generate new engines for innovation. Without the political pressure observed in the previous example, motivations are less obvious and thus the isomorphism is less prominent.

\section{c. Mimic market isomorphism: Energy efficiency Programs}

For corporations, climate change has broad effects: increased costs caused by different precipitation patterns, a growing cost of energy from greenhouse gas (GHG) laws, or non-adaptation risks. As a way to mitigate such risks, supply chain energy management is increasingly part of corporate climate change strategies. A growing number of companies, such as IKEA, Walmart and H\&M are working on programs to understand key GHG impacts in the supply chain and to identifyopportunities for improvement, such as amanagement plan for energy and GHG in the global supply chain, as well as engagement with suppliers to provide programs and tools for improvement of their own GHG emissions management. In recent years, an increasingly standard approach has been to involve suppliers in programs combining capacity building and giving access to tools for carbon footprinting, with the intent to allow suppliers themselves toreduce scope $3 \mathrm{GHG}$ emissions within their companies.

We assess such initiatives along the following lines:

- Stakeholder mapping is very limited. This is a business initiative. Other stakeholders than clients and suppliers are generally not directly consulted.

0 The initiative's ambition is to streamline cost.

- This is a proactive approach enabling companies to drive operational efficiency programs, and anticipating the rising cost of energy or more stringent regulations on carbon.

- Governance is limited. This is a supply chain partnership working under the stewardship of client companies

- Transformational process implies that efforts to agree on practices, tools and metrics to track progress. In that sense, while other stakeholders cannot feasibly visit companies and provide a 
third party check on suppliers' progress toward energy efficiency, there is still a robust framework to show progress over time since suppliers are accountable to report on their emissions with their clients.

\begin{tabular}{|c|c|c|c|c|c|}
\hline & $\begin{array}{l}\text { Stakeholder } \\
\text { mapping }\end{array}$ & $\begin{array}{l}\text { Motivations } \\
\text { \& interests }\end{array}$ & $\begin{array}{l}\text { Level of } \\
\text { ambition }\end{array}$ & $\begin{array}{l}\text { Level of } \\
\text { governance }\end{array}$ & $\begin{array}{l}\text { Transformational } \\
\text { change }\end{array}$ \\
\hline Mimic market & 2 & 2 & 5 & 3 & 4 \\
\hline
\end{tabular}

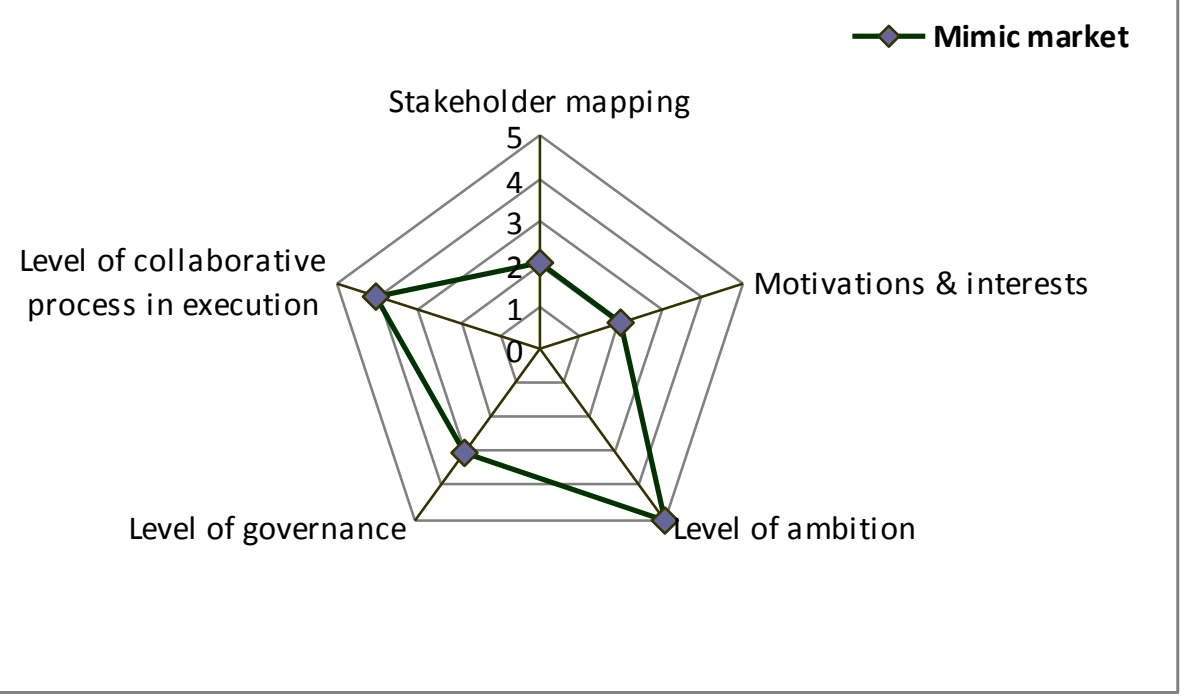

This empirical example shows the development of mimic isomorphisms. H\&M or IKEA's initiatives are developing under market pressure, and low intensity carbon in the supply chain mechanically fosters similar practices in the rest of the industry: over the past months, various competitors have esentially announced similar work on reduced-CO2 supply chain strategies. This example is a mimic isomorphism with limited direct implication of stakeholders beyond the core nucleus of a client and its direct supply chain companies. This system is, however, fairly easy to replicate and hasa strong business case which any company can easily understand.

\section{d. Social innovation market isomorphism: Nano-purification}

The World Health Organization claims that about 25 million people die every year from consuming water contaminated by toxins and viruses. In emerging economies, sanitation is often expensive and not accessible to the poor. Epicenter Biotechnologies is a manufacturer and reseller of molecular biology products for life science research, clinical research, molecular diagnostics and biopharmaceutical manufacturing. This company developed a nano-scale purification system-asimple bucket which filters water at nano level removing toxins and viruses in situ at extremely low costs. In theory, the solution is cheap and communities can pool their resources to buy a few buckets. In practice, raising awareness of targeted communities on water sanitation and developing the appropriate distribution channels has become the major challenge. This illustrates that technical innovation is not enough. Social innovation is required to define the appropriate business model to sell nano-filters among the appropriate communities.

We assess such initiatives along the following lines: 
- Stakeholder mapping is extensive. At a country or market level, buy-in from communities requires a fine-tuned understanding of all relevant stakeholders (community leaders, opinion formers, relevant authorities or administrations). Companies also need to define the appropriate tactics of engagement. That being said, while there aregood efforts to map and try to engage with stakeholders, there is limited information showing whether this has led to significant outcomes.

- The corporation is looking for a competitive advantage. It has its own patented technology, and develops its own business model to extensively distribute its own product.

- The company is looking at a breakthrough solution to provide access to safe water throughout the world, whereas most thinking around this issue is focused on the development of expensive (and often inadequate) infrastructures.

- Governance is limited. This is led by a company without strong involvement of stakeholders in the definition of the project. It involves commercially sensitive information, which explains why the company is not too open to share information about its production and distribution methods.

- Transformational process is also somewhat limited. Since the processes of manufacturing and distribution is sensitive, stakeholders have limited access to information related to the potential impacts of such solutions. Stakeholders have to conduct their own studies and may indeed challenge the company until they provide comparable information.

\begin{tabular}{|l|c|c|c|l|l|}
\hline & $\begin{array}{l}\text { Stakeholder } \\
\text { mapping }\end{array}$ & $\begin{array}{l}\text { Motivations } \\
\& \text { interests }\end{array}$ & $\begin{array}{l}\text { Level of } \\
\text { ambition }\end{array}$ & $\begin{array}{l}\text { Level of } \\
\text { governance }\end{array}$ & $\begin{array}{l}\text { Transformational } \\
\text { change }\end{array}$ \\
\hline & 4 & 4 & 5 & 2 & 3 \\
\hline
\end{tabular}

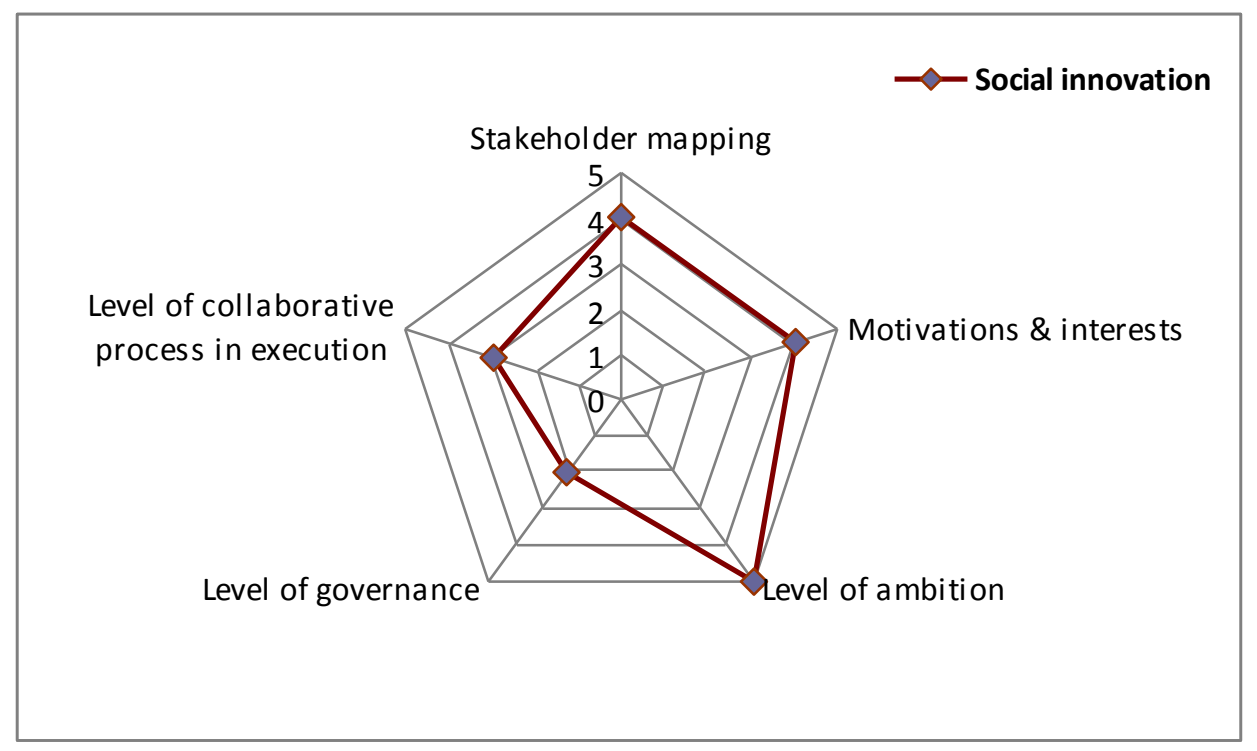

This empirical example shows how technologies, driven by social expectations in the market, can dramatically change business models. Sanitation requires costly sewer systems which most emerging countries cannot afford. The need to meet social expectations to over 4 billion poor people might indeed be the catalyst for technological development -technology which radically changes business models required to face major issues such as clean water. Closer engagement and contribution from stakeholders is indeed required (Anderson and Billou, 2007), since any initiative needs to take into account the unique institutional context of each emerging economy. Compared to all other isomorphisms, this one relies on a much more active level of interactions and engagement with stakeholders. 


\section{Conclusion}

Standard and acceptable business practices defined throughout the CSR negotiation processes drive changes in business strategies (O'Connor and Spangenberg, 2008). Corporations need to keep up with these changes or, to put it bluntly, will die. The examples of isomorphisms as outlined in this paper all align on the same patterns:

- Initiatives are driven by corporations,

- Initiatives are motivated by a common agreement on some of the sustainability issues to be tackled. Initiatives are generally based on indirect input from stakeholders

- Initiatives are generally weak in their ability to directly involve stakeholders in their developments

In our view, this approach outlines some trends which are illustrative of some of the key challenges of CSR today.

1. On the one hand, we say CSR is a contractual process defining relationships between stakeholders, driving decision making processes, setting expectations and agreeing on commitments between business and society.

2. On the other hand, examples all depict the development of isomorphism led by corporations, with very weak implication of their stakeholders.

As a result, this paper puts forward the following questions:

- Systems of stakeholders do not talk to each other. Real world examples show there is indeed limited cooperation and interaction between different systems of stakeholders. Beyond theories, how can systems of stakeholders can develop practical models for cooperative work?

- Management structures within corporations do not enable external engagements. We question the extent to which management is trained, as well as the way operations are managed. Do they enable cooperation, and the ability to work in a more open manner with external stakeholders?

- CSR and responsible development. CSR is the corporation's contribution to the wider challenge of sustainability. Our examples show that CSR is no more than the achievements of fragmented initiatives led by companies showing limited transparency toward external stakeholders. There is no overall coordination. Should not public authorities play a more strategic role showing clear direction, and establish themselves as a strategic platform enabling more engagement between stakeholders?

\section{Bibliography}

Anderson J. and Billou, N. (2007), "Serving the world's poor: innovation at the base of the economic pyramid", Journal of Business Strategy, Vol. 28, n², pp.14 - 21

Baddache, F. (2004), Entreprise et ONG face au développement durable. L'innovation par la coopération, L'Harmattan, France.

Barabel, M., Combes, M., Meier, O. and Nicolaï, I. (2010), "Perception and Legitimation of CSR within a Multinational Firm: the Case of Dexia Group" Revue Internationale de Psychosociologie

Boiral, O. (2006), "Global Warming: Should Companies adopt a proactive strategy", Long Range Planning, Vol. 39, n³, pp.315-330

Deephouse, D.L. (1996), "Does isomorphism legitimate?", Academy of Management Journal, Vol 39, $\mathrm{n}^{\circ} 4$, pp.1024-39

DiMaggio, P. J. and Powell, W. (1991), "The iron cage revisited: Institutional isomorphism and collective rationality in organizational fields", in W. W. Powell \& P. J. DiMaggio (Eds.), The new institutionalism in organizational analysis, pp. 63-82, Chicago: University of Chicago Press.

Fassin, Y. (2009), "The stakeholder model refined", Journal of Business Ethics. 
Freeman, R.E. (1984), Strategic Management: A Stakeholder Approach, Marshfield, MA: Pitman.

Garriga, E. and Mele, D. (2004), "Corporate social responsibility theories: mapping the territory", Journal of Business Ethics, vol.53, n²1/2, pp.51-71.

Habermas, J. (1991), De l'éthique de la discussion, traduction française 1992, Paris, éditions du Cerf.

Hall, J. and Vredenburg, H., (2005), "Managing Stakeholder Ambiguity", MIT Sloan Management Review, Vol. 47, n¹, pp. 11-13.

Hill, C. and Jones, T. (1992), "Stakeholder - Agency Theory", Journal of Management Studies, vol.29, $\mathrm{n}^{\circ} 2$, pp. 133-154.

Kahler, M. (2009), "Networked Politics: Agency, Power, and Governance", in M. Kahler (ed.) Networked Politics: Agency, Power, and Governance. Ithaca: Cornell University Press, pp. 1-20

Karnani, A. (2007), "The mirage of marketing to the bottom of the pyramid: how the private sector can help alleviate poverty", California Management Review, Vol. 49, n4, pp.90-111

O'Connor M., Spangenberg J.H., (2008), "A methodology for CSR reporting: assuring a representative diversity of indicators across stakeholders, scales, sites and performance issues", Journal of Cleaner Production, Vol. 16, n¹3, pp. 1399-1415

Oliver C. (1991), "Strategic Responses to Institutional Processes", Academy of Management Review, Vol.16, n¹, pp.145-179.

Porter, M.E. and Kramer, M.R. (2010), "The Big Idea: Creating Shared Value", Harvard Business Review

Prahalad, C.K. and Hammond, A. (2002), "Serving the world's poor profitably", Harvard Business Review.

Sugden, R. (1989), "Spontaneous order", Journal of Economic Perspectives, Vol. 3, n4, pp.85-97

Van den Hove, S. (2006), "Between consensus and compromise: acknowledging the negotiation dimension in participatory approaches", Land Use Policy, Vol. 23, n 1, pp.10-17 